\title{
Double Resonance Method for Determination of Gel Point
}

\author{
Ivan S. Kozhevnikov, Lyubov K. Altunina, \\ Andrey V. Bogoslovsky and Lyubov. A Stasyeva* \\ Institute of Petroleum Chemistry SB RAS \\ 4 Akademichesky, Tomsk, 634055, Russia
}

Received 25.12.2018, received in revised form 18.02.2019, accepted 09.04.2019

The application of double resonance method for determining the dynamics of fluidity changes of thermotropic gel-forming compositions based on cellulose ether is considered. To determine the gel point, a modified version of the 'Rheokinetika' viscometer including two identical sensors and measuring cells of different diameters.

Keywords: gel point, gel-forming compositions, vibrational viscometry.

Citation: Kozhevnikov I.S., Altunina L.K., Bogoslovsky A.V., Stasyeva L.A. Double resonance method for determination of gel point, J. Sib. Fed. Univ. Chem., 2019, 12(2), 160-165. DOI: 10.17516/1998-2836-0115.

\section{Метод двойного резонанса}

\section{для определения точки гелеобразования}

И.С. Кожевников, Л.К. Алтунина,

А.В. Богословский, Л.А. Стасьева Институт химии нефти СО РАН

Россия, 634055, Томск, пр. Академический, 4

Рассмотрено применение метода двойного резонанса для определения динамики изменения текучести термотропных гелеобразующих композииий на основе метилцеллюлозы. Для определения точки гелеобразования использован модифицированный вискозиметр «Реокинетика», содержащий два идентичных датчика и измерительные ячейки различных диаметров.

(C) Siberian Federal University. All rights reserved

* Corresponding author E-mail address: tsu@gmail.com 
Ключевые слова: точка гелеобразования, гелеобразующие композиции, вибрачионная вискозиметрия.

\section{Introduction}

Gel-forming compositions (GFC), widely used for isolation of oil reservoir fragments, and filtration streams redistribution, are solutions that lose their fluidity and form gels in the course of their application [1-3].

The most important performance characteristic is the gel point, which might be the time-point or the temperature of change in fluidity (loss in fluidity in the critical case). Gel point is characterized by a change in the viscosity of sample and the occurrence of elasticity and manifests itself in rheological measurements. However, its determination is a nontrivial task, especially in the case of high initial viscosity, which can mask the occurrence of elastic properties.

To control the kinetics of gel formation, a vibration method was previously proposed. In the course of the experiment, the viscosity-related inhibitory force was determined. This force acts from liquid side on a probe vibrating in a liquid. The vibration method was originally developed to measure the viscosity of low-viscous Newtonian fluids. Therefore it is successfully used to characterize initially low-viscous GFCs. This paper deals with the application of vibration method to control the kinetics of gelation, i.e. loss in fluidity of polymer-containing compositions, including those having an increased initial viscosity value.

In the course of experiment, a probe immersed in a liquid radiates into the surrounding space a shear wave whose damping rate is related to the characteristics of the controlled medium. If the object of measurement is a Newtonian fluid, then the wave quickly decays, so the measuring vessel could be considered infinite. During the formation of gels, fluidity is lost. Hence, transfer of such a wave from the probe to the wall of the vessel and its reflection and interference of the emitted and reflected waves become possible. In this case, the vessel could not be considered infinite.

The result of the measurement becomes dependent on its dimensions and quasiperiodic fragments associated with interference appear on the resulting curve. It was shown in [4] that the envelopes of the interference curves registered in this case are shifted with an increase of the measuring cell in size towards a stronger structure, while the range of divergence of the rheokinetic dependencies obtained in measuring vessels of different sizes corresponds to the onset of gelation. The technical base of the method under consideration is a vibrational viscosimeter. In particular, a 'Rheokinetika' viscometer developed at the Institute of Petroleum Chemistry of the SB RAS is designed for the study of structure formation processes.

\section{Subjects of investigation and experimental method}

We used a modified version of the 'Rheokinetika' viscometer including two identical sensors and two thermostat shirts for measuring cells of different diameters, i.e. double resonance viscometer (Fig. 1). The device is equipped with two identical probes and two thermostat shirts for measuring cells of different diameters (d).

The basic building block of device is a vertical support stand with two rods. It is heavy base includes the power source of device, while the indicator and the power switch are located on the base 


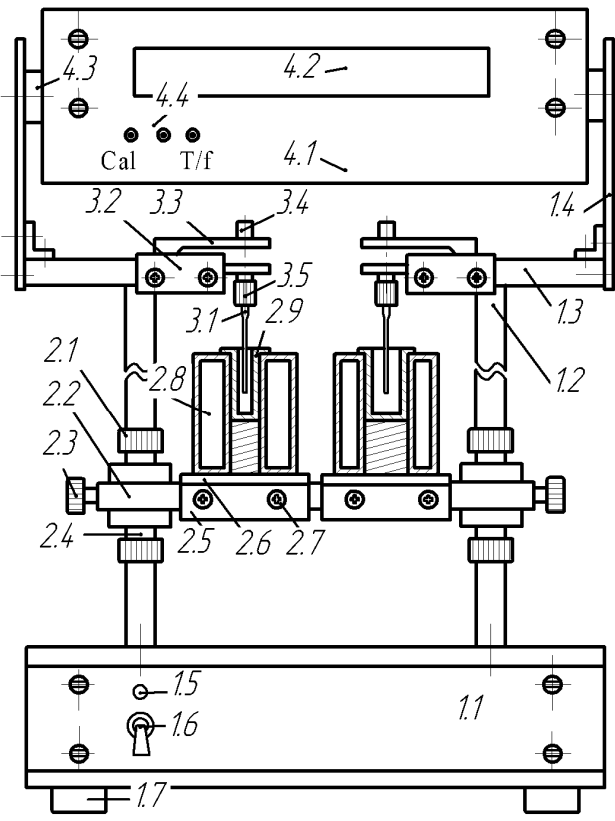

Fig. 1. Double resonance viscometer: 1 - stand: 1.1 - base, 1.2 - guide rods, 1.3 - fixed platform, 1.4 - vertical plate, 1.5 - power indicator, 1.6 - power switch, 1.7 - base legs; 2 - mobile platform with cell unit: 2.1 - holddown nut, 2.2 - motion platform, 2.3 - retention screw, 2.4 - vertical slide, 2.5 - horizontal slide, 2.6 - support plate, 2.7 - retention screw of measuring cell unit, 2.8 - thermostat-jacket, 2.9 - measuring cell; 3 - sensor unit: 3.1 - probe, 3.2 - sensor housing, 3.3 - tuning fork, 3.4 - counterweight, 3.5 - collet; 4 - control unit: 4.1 - front panel, 4.2 - display, 4.3 - cylindrical insert, 4.4 - viscometer adjustment buttons

front. Two thermostat-jackets including measuring cells are located on the horizontal sliders of the mobile platform.

The viscometer is equipped with 10,12 and $15 \mathrm{~mm}$ sized cells. The vibration viscosity sensors are located on the fixed platform, which is connected to the base by means of the rods. The tuning forks of vibration viscosity sensors are coupled to the probes. The probes are glass rods of $4 \mathrm{~mm}$ diameter with an elongated test section. The control unit at the top of viscometer is connected to two vertical plates by means of the cylindrical inserts. The control unit provides oscillating motion of the probes and continuous data transmission to the attached computer.

The output signal from the viscometer sensor, the voltage $\mathrm{U}, \mathrm{mV}$, is proportional to the value of mechanical $\mathrm{Z}$ resistance, which is directly related to the viscosity $\eta$ and the density $\rho$ of the tested sample. Relative values are used:

$$
Z_{r e l}=\frac{U-U_{\text {air }}}{U_{\text {ref }}-U_{\text {air }}}=\frac{(\rho \eta)^{0.5}}{\left(\rho_{\text {ref }} \eta_{\text {ref }}\right)^{0.5}}
$$

where $\rho_{\text {ref }}$ and $\eta_{\text {ref }}$ are the density and viscosity of the reference, respectively.

The $U_{\text {air }}$ and $U_{\text {ref }}$ values corresponding to the probe motion in air and in reference liquid are recorded at the beginning of each measurement. In the course of the kinetic experiment, the $U_{i}$ value of current signal is continuously recorded using an attached computer. Further, $Z_{\mathrm{i}(\text { (ref) }}$ is calculated for each $U_{i}$ value by the formula (1). The final measurement result is the dependence of mechanical $Z_{\text {rel }}$ resistance on time or temperature. 
The curve of typical dependence could be divided into three specific regions:

1 - practically horizontal region corresponding to the solution formed immediately after initiation,

2 - region of monotonic increase in mechanical resistance of viscosity, and

3 - the extreme right quasiperiodic fragment.

This dependence is more or less distinctly manifested in the behavior of most real objects. Next, consider the experimentally obtained rheokinetic curves.

The following objects were used as test objects:

GFC-1 - thermotropic GFC based on polymer with LCST - cellulose ether, with addition of electrolyte;

GFC-2 - thermotropic GFC based on cellulose ether with the addition of electrolyte and glycerin.

The compositions were prepared by dissolving the weighed amount of components in distilled water with constant stirring at room temperature. In order to continuously register the mechanical resistance, the samples prepared were placed into measurement cells.

In order to continuously register the mechanical resistance, the samples prepared were placed into measurement cells. Distillated water was used as a reference. The cells of different diameters were filled with the GFC-1 and GFC-2 solutions under study.

Each cell was inserted into a thermostat-jacket of the appropriate size. Prior to each measurement, the $U_{\text {air }}$ and $U_{\text {ref }}$ values were registered. Further, each sample was heated from 25 to $60{ }^{\circ} \mathrm{C}$ for continuous recording the output signal from the viscometer $\left(\mathrm{U}_{\mathrm{i}}\right.$ voltage $)$. The $\mathrm{Z}_{\text {rel. }}$ values were calculated using the formula (1) and then $\mathrm{Z}_{\text {rel. }}-$ temperature curves (Fig. 2A, 3A) and their envelopes were plotted (Fig. 2B, 3B).

\section{Results and discussion}

Dependences of the relative mechanical resistance on the temperature for the GFC-1 composition are presented in Fig. 2A. The curves plotted for all measuring vessels practically coincide within the range from 25 to $40^{\circ} \mathrm{C}$, as well as their envelopes (Fig. 2B).

The viscosity of solutions decreases slightly with increasing temperature. The curves begin to diverge at point of $40{ }^{\circ} \mathrm{C}$. The position of fragments showing rapid changes in the mechanical resistance and extrema of the right quasiperiodic regions shifts with an increase in the cell diameter toward a stronger structure, i.e. higher temperature. The gel point, defined as the point of divergence of envelopes is about $40{ }^{\circ} \mathrm{C}$.

The dependencies obtained for GFC-2 (Fig. 3A) are typical and their curves show the same characteristic fragments. The initial regions of the plots (from 25 to $45{ }^{\circ} \mathrm{C}$ ) obtained with the use of different cells coincide. However, the corresponding $Z_{\text {rel }}$ value for the GFC-2 composition is higher than that for the GFC-1 composition by two relative units due to the higher initial viscosity caused by the presence of glycerol.

The local minimum of the curves reached at $45{ }^{\circ} \mathrm{C}$ is due to a decrease in the viscosity of the glycerol-containing solution with an increase in temperature in the region below the gel point. It is followed by regions of rapid monotonic increase in $\mathrm{Z}$ at $45{ }^{\circ} \mathrm{C}$, where the result obtained for $\mathrm{d}=12$ practically coincides with that obtained for $\mathrm{d}=15$. After $47.5^{\circ} \mathrm{C}$, the curves and their envelopes diverge and the clearly pronounced quasiperiodic fragments begin. 


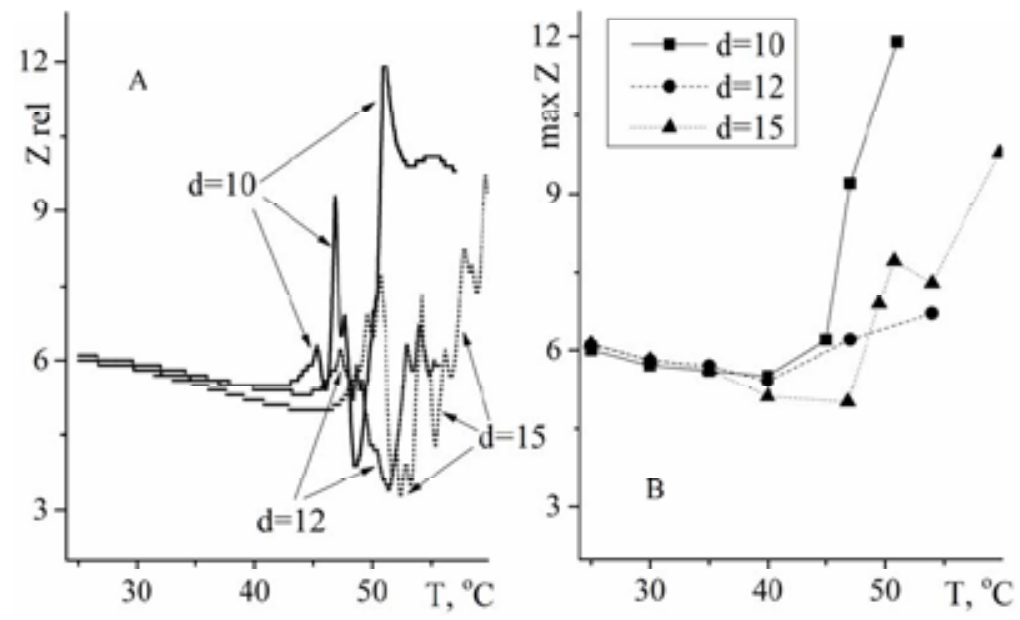

Fig. 2. Dependences of the relative mechanical resistance on the temperature of GFC-1 (A) and envelopes of curves of these dependencies (B)
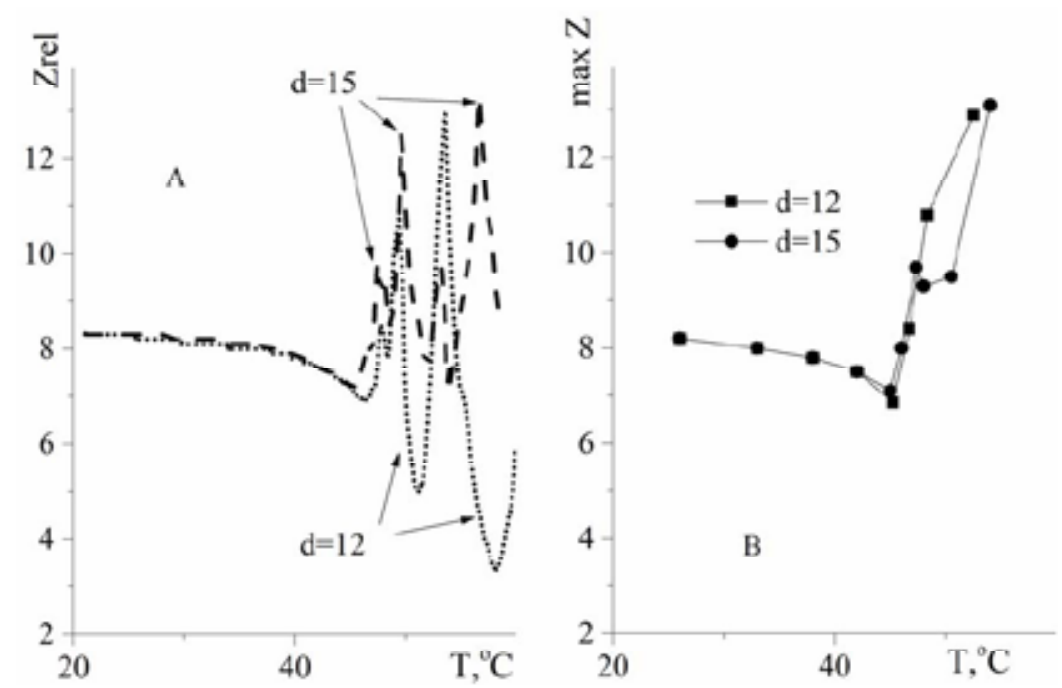

Fig. 3. Dependences of the relative mechanical resistance on the temperature of GFC-2 (A) and envelopes of curves of these dependencies (B)

Their positions and amplitudes depend on the size of used measuring vessel. As the cell increases in size, the envelopes (Fig. 3B) are shifted towards a stronger structure, hence the temperature $47.5^{\circ} \mathrm{C}$ can be considered as the gelation temperature.

\section{Conclusions}

Thus, the point of fluidity loss (gel point) has been determined and kinetics of gelation has been recorded for thermotropic GFCs, having different initial viscosity levels and different compositions. It has been shown that the envelope comparison method and the double resonance viscometer could be used to determine gel points of thermotropic GFC. 


\section{Acknowledgments}

The work was supported by the Ministry of Education and Science of the Russian Federation under the Agreement for the Grant of Subsidies No. 14.604.21.0176 of September 26, 2017, the unique identifier RFMEFI60417X0176 within the framework of the Federal Target Program "Research and Development in Priority Areas of Research and Technological Complex of Russia for 2014-2020" in the priority area "Rational Nature Management". The work was performed using the equipment of the Center for Collective Use of TSC SB RAS and the Center for Collective Use of NR TSU.

\section{References}

1. Altunina L.K., Kuvshinov V.A. Physicochemical methods for enhancing oil recovery from oil fields. Russian Chemical Reviews 2007. Vol. 76(10), P. 971-987.

2. Manyrin V.N., Shvetsov I.A. Physicochemical Methods for Enhanced Oil Recovery using Water Flooding. Samara: Samarskii Dom Pechati, 2002. 391 p. (In Russ.)

3. Gazizov A.A Enhanced Oil Recovery from Hetero-geneous Formations in Late Stages of Development. Moscow: Nedra-Biznestsentr, 2002. 639 p. (In Russ.)

4. Bogoslovsky A.V., Galkin V.M., Kozhevnikov I.S. Determination of geletion moment by measurement cells of various size. Gas Industry of Russia 2013. Vol. 698(11), P. 98-100. (In Russ.) 